\title{
Social Capital and Socio-demographic Changes: From Non-differentiation to Multifocalisation
}

\author{
Renato Miguel Carmo* and Sofia Santos
}

\begin{abstract}
This article examines how different socio-demographic trends interrelate with alterations in the traditional forms of social and interpersonal relationships. We will focus on two Portuguese municipalities using the concept of rural community as an analytic starting point for framing and examining the different dimensions of social capital. The survey's data shows that the generalised nature of mutual knowledge and trust, that used to characterise more traditional communities, tends now to depend on new social categories and groups that live and interact in these places. The study contains a multivariate, multiple correspondence analysis, which shows three different profiles of social capital coexisting in the two areas.
\end{abstract}

\section{Introduction}

$I^{n}$ $\mathrm{n}$ the last two decades, the concept of social capital has become one of those most analysed and discussed in different areas of the social sciences addressing very different social and geographical realities. Certain authors believe that this wide use has resulted in the loss of meaning of the concept itself, in that it covers a complex series of dimensions that are difficult to define either conceptually or empirically (Portes I998; Anderson and Bell 2003). Others have drawn attention to the different more or less harmful appropriations of the concept by a number of national or global political institutions (Harriss 200I). We consider that is possible to conceptualise and to analyse social capital as a structural set of variables (Foley et al. 200I; Johnston et al. 2005; Nguyen 20I0) that will enable us to go deeper in the study of distinct sociological dimensions such as trust, associative engagement, and social networks. To address these dimensions in a local context we developed a survey in two Portuguese southern municipalities that represent distinct dynamics of growth and stagnation in rural territories. 
The article will firstly address some relevant theoretical questions related to social capital in the framework of rural communities' studies. Secondly the case studies are presented in their demographic and socioeconomic portraits representing different faces of rural development tendencies. We shall then analyse the results from the survey which draw upon dimensions of social capital: levels of trust and knowledge within neighbours, of civic engagement and of focalised or more privileged social contacts inside or outside the municipality. The analysis of these dimensions crosses the socio-demographic features of the population, including mobility practices, with the different types of social capital. Finally, a global synthesis is developed resulting from a multivariate analysis showing three profiles of social capital that coexist in the two areas. In this multidimensional analysis we first identified the general profiles of social capital building (multicorrespondence analysis) and then we group individuals (clusters analysis) according to these profiles, being able to confirm the readings on the relations between social capital building, socio-demographic features and spatial processes.

The central idea behind the theory of social capital is the value of social links or ties that allow people to make contact with one another and ultimately lead to increased levels of social cohesion and wellbeing in a group or a community (Carmo 20I0). The analysis in this article is developed within the framework of rural community studies (Wilshusen 2009; Campbell et al. 20I0; Dale and Newman 2010). The most pertinent dimensions were defined for the study of two local communities in inland Portugal that are undergoing different socio-demographic trends. They are São Brás de Alportel (SBA), which has experienced considerable demographic growth in the last 30 years, especially in the I990s, and Alcoutim, which continues a path of significant marginalisation, as shown by indicators such as on-going aging and depopulation. The study is based on a survey of the residents of each municipality.

These different socio-demographic trends interact with the alterations that have taken place in more or less traditional forms of social and interpersonal relations. The concept of rural community is a starting point for the analysis and enables us to situate the different dimensions of social capital identified. Here, it is not a question of redefining the concept of community, although we consider this a highly interesting discussion. It is rather a question of understanding the impact of sociodemographic changes with reference to the fundamental elements and traits that used to characterise rural communities. A very cautious analysis is therefore made of these two concepts that have fuelled such heated scientific discussions. We will explore the analytical potential of the concept of social capital within a consistent interpretation of social phenomena in local communities.

\section{Social capital and rural communities}

As mentioned above, the purpose of this article is not to conduct a theoretical analysis of the concept of community and its greater or lesser applicability to contemporary social realities. We do, however, feel that it is pertinent to use this concept as a starting point for a study of the forms of social capital in rural areas undergoing different socio-demographic processes. Thus we intend to challenge both the idea of community - as a declined concept composed by homogenous and closed forms of identity 
and solidarity practices - and that social capital is equally fixed. According to several authors (Amit 2002) rather than look at community as a 'decline narrative' it is important to conceive it as a reconfiguration process. The article will develop this perspective by looking at the changing balance between different types of social capital.

According to Nisbet, 'Community includes but goes beyond local community to encompass religion, work, family and culture, it refers to social bonds characterised by emotional cohesion, depth, continuity and fullness' (Nisbet I966, p. 6). This general definition points to three crucial aspects. The community's spatial perimeter goes beyond a local scale, the relationship between members of the same community tends to be intense and exclusive (bonding) and there is a continuity and totality in these relationships. Traditionally, a community is regarded as a homogeneous, closed social system whose members share identity factors that are reflected in regular forms of social solidarity (Bell and Newby I97I).

A community is normally associated with a small local territory (which may be a village, a town or even a neighbourhood). Redfield's (I960) definition of the folk society was situated at one of the ends of the rural-urban continuum, in which size was considered to be one of the most decisive elements of its social composition. Many studies on communities have focused precisely on rural villages and settlements, in which they identified some of the ecological and social characteristics mentioned by Redfield (Bell and Newby I97I).

According to Amit '(...) community has been a long-standing, although by no means an exclusive, conceptual medium for interrogations of the interaction between modernity and social solidarity. Far from side-lining this preoccupation, recent changes in the nation-state form, patterns of mobility, communications, technology and transnational connections have surely spotlighted it even further' (Amit 2002, p. 2).

The concept of community should therefore include '(...) a dynamic reality marked by the past, the juncture and events and permeated by centripetal or centrifugal forces. The former include socio-spatial affinity or proximity, common habits and acts of concrete solidarity between participants. The latter comprise economic, social or cultural difference, diverging lifestyles and inequality in terms of power' (Sobral I999, pp. 45-46). Regarding this perspective we agree with the idea defended by Amit that 'community was not simple locale; like the small-scale societies of the earliest ethnographies, it had become the nexus of an inextricable convergence between cultures, place intricate social relations and collective identity' (Amit 2002, p. 5).

As certain authors have observed (Mendras 1976; Pinto I985; Rémy and Voyé I994), rural communities were marked by considerable mutual knowledge, which was expressed in degrees of interpersonal trust and cultural and symbolic belonging to the same collective identity, among other aspects. Mutual knowledge resulted in a series of bonding relationships (farm and neighbourhood work, etc.), while people shared systems of values and similar language codes (Carmo 2009).

Although the concept of social capital is not mentioned in these or other studies of rural communities, it is not unreasonable to include it as a fundamental element in the reproduction of structures and social networks (Frykman et al. 2009). There are different definitions of the concept, though all point to the fact that it focuses on the 
importance of social relations and considers them to be an important form of capital, just as human and economic capital are deemed important (Woolcock I998). In turn, most of these perspectives consider that social capital is generated and fuelled by interaction between fundamental dimensions: social networks, greater interpersonal trust and higher social norms and values (Portes I998; Shuller et al. 2000; Lin 200I; Van Deth 2003; Halpern 2005).

In addition to these three dimensions, authors such as Putnam (I993, 2000) place particular emphasis on associative density and forms of civic engagement as an essential indicator for the deepening and consolidation of democratic systems. The diversity and intensity of associative life are therefore a structural factor in the promotion of social engagement in its different expressions. Putnam identifies two different types of social capital, bonding and bridging. While bonding is exclusive and based on the consolidation of the collective identity, strong ties and the homogeneity of social groups, bridging relates to more external relationships set up by heterogeneous social networks, many of which are fuelled by weak ties, according to Granovetter (I973).

Relationships of mutual knowledge and social closure are essential in increasing social capital, as clearly pointed out by Bourdieu (I980) and Coleman (I990). In a sense, these two authors, who were responsible for founding the concept in sociology, basically stressed bonding as an essential condition for the creation and reproduction of social capital.

The transformation processes that took place in contemporary societies, including those in rural areas, have wrought not only a profound change in the meaning of the concept of community (Worsley I970; Ficher I977; Wellman I979; Calhoun I980), but also gave a new focus to the different dynamics in the production of social capital. Therefore, where rural areas are concerned, factors associated with globalisation, urbanisation and tertiarisation of the economy have caused structural changes that have been studied and documented in recent years (Kayser I990; Jollivet I997; Perrier-Cornet and Hervieu 2002; Woods 2007).

These and other associated phenomenon mean that bonding has become less dominant in rural communities and other forms of relationship, more similar to bridging, have emerged (Falk and Kilpatrick 2000; Schucksmith 2000; Svendsen and Svendsen 2004; Lee et al. 2005; Shortall 2008; Magnani and Struffi 2009; McAreavey 2009; Nardone et al. 2010).

The impact of spatial mobility in rural areas, especially the intensification of connections with more urban areas, has resulted in greater openness and diversification of social ties, which have gradually become less exclusive (Camarero I993; Murdoch 2000; Milbourne 2007; Carmo 2010; Hedberg and Carmo 20I2). As Urry mentions 'social capital depends upon the range, extent and modes of mobility, especially vis-à-vis the mobilities of other social groups. Interventions that reduce, channel or limit such mobilities will weaken social capital and generate new forms of social exclusion' (Urry 2002, p. 265).

Even though studies of traditional communities have not specifically analysed the issue of social capital, it is possible to say that many of the bonding mechanisms were dominant in certain rural communities. Therefore not much room is left for the appearance and development of others based on less exclusive and homogeneous 
forms of social capital. On a community scale, relationships of mutual knowledge and interpersonal trust developed and tended to submerge different individual identities in a strong collective identity.

High levels of trust and interpersonal knowledge within communities have therefore ceased to have this nature of fullness mentioned by Nisbet (1966) and now coexist with other forms of relationship generated by the social transformations that have taken place in the meantime (Calhoun I991). Although bonding continues to be an identifying, structuring feature of rural communities, it has lost that totality stemming from a strong collective and social identity, among other factors. According to Liepins, "the practices of "community" include the range of formal and informal ways people conduct their economic, social and political life' (Liepins 2000, p. 3I).

In addition to relations with the outside, these changes have also had an increasing impact within the localities themselves. In fact, while general levels of trust and mutual knowledge persist to a certain extent in many rural communities, they have given way at least partially to more directed, focused forms of relationship that tend to differ on the basis of membership of different social groups. In other words, rural communities have lost this totality that traditionally characterised them, due in part to the socio-demographic changes that they have undergone.

This dynamic nature that affects many rural communities is not unconnected to the diversification of forms of social capital that have developed there. Indeed, a strong interdependency is generated between distinct socio-demographic trends and the complexification of bonding and bridging as forms of social capital. To a certain extent, this has been tested by recent works on the creation and reproduction of social capital in rural areas, which mainly stress their relationship with diverse initiatives and processes of local development (Falk and Kilpatrick 2000; Schucksmith 2000; Svendsen and Svendsen 2004; Lee et al. 2005; Shortall 2008; Magnani and Struffi 2009; McAreavey 2009; Carmo 2010; Nardone et al. 2010).

The hypothesis to be measured in this article is that these forms of social capital have ceased to consist almost exclusively of bonding to gradually include other variants more focused on diverse, specific social relationships and connections. The generalised $^{\mathrm{I}}$ nature of mutual knowledge and trust that characterised more traditional communities tends today to depend on the new groups and different social categories interacting in these same places. We are going to look into the different levels of mutual trust, the types of knowledge networks and the participation in associations ${ }^{\mathrm{I}}$ in each municipality and correlate them with a set of characterising variables such as age, school attainment, social class, etc. Through the multivariate analysis three distinct sociological profiles will come out from the statistical relation between these variables.

\section{Case studies: the two municipalities}

In order to test this hypothesis, we will use the results of recent research on two Portuguese municipalities in the Algarve region (southern Portugal, see Figure 1): São Brás de Alportel (SBA), which has Io,662 residents and Alcoutim, with 2,9I7 residents (INE 20II). A questionnaire was given to a representative sample of the resident population in the two municipalities. ${ }^{2}$ Around 4 IO questionnaires were administered 


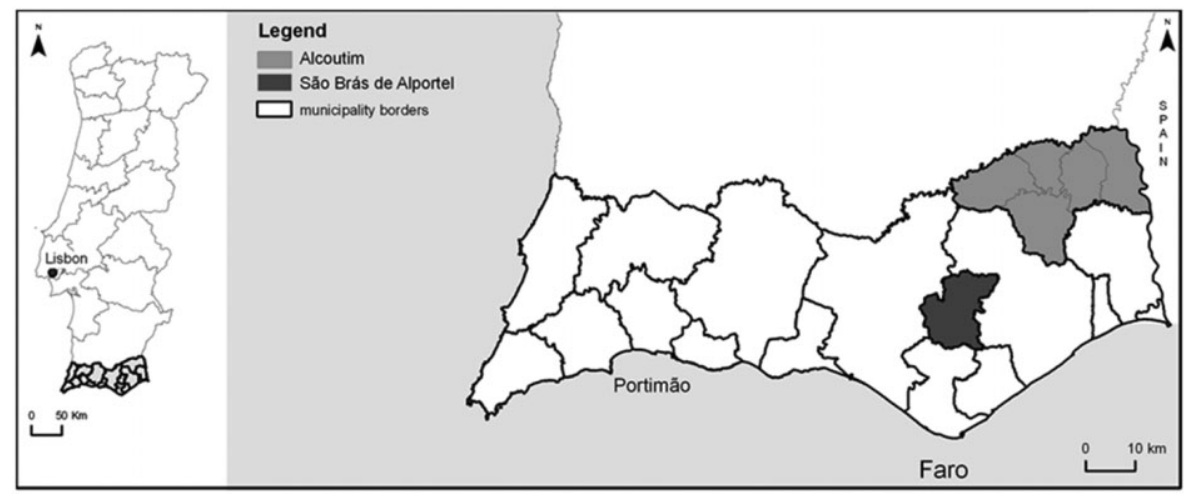

Figure 1: Location map

between July and September 2009 in SBA and 268 in Alcoutim. The script covered the following dimensions: (I) commuting and other travel practices to neighbouring cities, (2) sociability relationships and interpersonal trust between neighbours, (3) forms of civic engagement and membership of associations and (4) social representations on the future of the municipalities. The data addressed in this article have to do with the second and third points.

These municipalities were selected for a comparison between two areas that, although they are both in the inland hills, have now opposing socio-demographic dynamics. SBA, which is a little over $20 \mathrm{~km}$ from Faro, the region's largest city, was originally an agricultural municipality, but in the last two decades it has undergone profound changes, which are reflected in a substantial increase in its resident population. Alcoutim is further east, on the border with Spain, and has shown increasing trends towards depopulation and aging.

In this context, SBA has shown an exceptional population growth in the last decades. Its population rose by 33.3 per cent between I99I and 200 I and continued to increase more recently (25.3 per cent between 200I and 2008). Fundamental to this growth/marginalisation duality is the aging process: in 2008 nearly 40 per cent of Alcoutim's population was over 65 years old and that percentage was 44 per cent in 20II, when in SBA the value was almost half of it (22.3 per cent in 200 I and 22.4 per cent in 2OII).

More recently with the context of economic crisis, this growth has slowed down though not completely. Recalculating the growth between $200 \mathrm{I}$ and $20 \mathrm{II}-$ year of our last census - it has registered a growth of 6.3 per cent.

In spite of its inland location, this municipality has become integrated in the urban system around Faro and has shown a highly accentuated growth dynamic. The repercussions of the municipality's population growth include an increase in the young population (from $200 \mathrm{I}$ and 2008 population has risen $\mathrm{I} 5.8$ per cent in the I4 and under age group and 13.5 per cent in the 15 to 25 age group). There is also a relevant percentage of the population working or studying outside the municipality: around 35.9 per cent in $200 \mathrm{I}$ which rose to 4I.6 per cent in $201 \mathrm{II}$ (higher than the regional or national values: 23.4 per cent and 34.3 per cent in 20II). 
Alcoutim is a more marginalised municipality, suffering accentuated, on-going population loss in the last 20 years. Its population is considerably older and with lower school attainment. Indeed, between 200I and 2008 the age groups under 25 years old showed greatest losses: -3 I. 8 per cent of young people up to I4 years old and -42.5 per cent of people between I5 and 25 years old. Compared with SBA, Alcoutim shows a large proportion of people of working age that are employed in the municipality. In 200I, just over Io per cent of the employed population was commuting to work or study and in $201 \mathrm{II}$ that percentage rose to I5.5 per cent. This reflects a more segregated municipality where if people do not find work locally they end up moving out, as it is quite difficult to keep on living there and work elsewhere.

Regarding the employed population by sector, the primary sector is very important in Alcoutim, accounting for I8.9 per cent of the employed population in 200 I and still 9.8 per cent in 20II, compared to SBA (2.9 per cent in 200I and I.5 per cent in 20II) or even in the region (6.I per cent in $200 \mathrm{I}$ and 3.3 per cent in 20II). The difference can also be found in the educational profile as SBA has a higher percentage of people with a college degree (7.5 per cent in $200 \mathrm{I}$ and I3.5 per cent in 20II), slightly higher than the region's level (7.3 per cent in $200 \mathrm{I}$ and I3.3 per cent in 20II) and nearer to the national value (8.6 per cent in $200 \mathrm{I}$ and I5.I per cent in 20II). This has been a dimension that has continually improved all over the country these last decades. Nonetheless, the profoundly aging character of the population of Alcoutim has prevented a better performance at this level (2.3 per cent in $200 \mathrm{I}$ and 4.3 per cent in $20 \mathrm{II}) .^{3}$

SBA is a municipality that keeps rural features on its landscape, dimension and other aspects at the same time it has been growing. Here workers of the regional capital or of other places can live with a better quality of life and keep working elsewhere. Alcoutim is a symbol of a depressed rural space that has been losing population, services and economic activities. It lacks the ability to attract workers or inhabitants that work outside, due to its geographical isolation. Mobility is a strong condition in local development.

\section{Social capital dimensions: trust, networks and membership of associations}

As mentioned above, although social capital fits into a very broad, varied series of dimensions, there are at least three that constitute a kind of hard core of the concept. They are mutual knowledge and trust, social networks and civic engagement and membership of associations. We used the script of the questionnaire administered to record different aspects of social capital and achieve an understanding of how they vary, based on the sociological and geographical variables considered. The analysis starts with a general overview of social and trust relationships and then looks at the most favoured types of knowledge networks and forms of civic engagement and participation in associations.

\section{Mutual knowledge and trust}

The presentation of the empirical data begins with the question of mutual knowledge. The percentage of respondents who said that they knew all or almost all their neighbours was considerable in both municipalities, at 86.7 per cent in Alcoutim and 
Table 1: Trust in neighbours by age groups

\begin{tabular}{lccccc}
\hline & & \multicolumn{3}{c}{ Age } & Total \\
\cline { 3 - 5 } & & Up to 35 & $35-64$ & 65 and over & \\
\hline São Brás de Alportel & In all & 20 & 51 & 67 & 138 \\
& & $21.7 \%$ & $30.5 \%$ & $47.9 \%$ & $34.6 \%$ \\
& In most & 19 & 49 & 28 & 96 \\
& & $20.7 \%$ & $29.3 \%$ & $20.0 \%$ & $24.1 \%$ \\
& In some & 42 & 56 & 38 & 136 \\
& & $45.7 \%$ & $33.5 \%$ & $27.1 \%$ & $34.1 \%$ \\
& In none & 11 & 11 & 7 & 29 \\
& & $12.0 \%$ & $6.6 \%$ & $5.0 \%$ & $7.3 \%$ \\
& Total & 92 & 167 & 140 & 399 \\
& & $100.0 \%$ & $100.0 \%$ & $100.0 \%$ & $100.0 \%$ \\
& In all & 19 & 78 & 50 & 147 \\
& & $45.2 \%$ & $54.2 \%$ & $62.5 \%$ & $55.3 \%$ \\
& In most & 7 & 34 & 18 & 59 \\
& & $16.7 \%$ & $23.6 \%$ & $22.5 \%$ & $22.2 \%$ \\
& In some & 12 & 29 & 11 & 52 \\
& & $28.6 \%$ & $20.1 \%$ & $13.8 \%$ & $19.5 \%$ \\
& In none & 4 & 3 & 1 & 8 \\
& \multirow{2}{*}{ Total } & $9.5 \%$ & $2.1 \%$ & $1.3 \%$ & $3.0 \%$ \\
& 42 & 144 & 80 & 266 \\
& $100.0 \%$ & $100.0 \%$ & $100.0 \%$ & $100.0 \%$ \\
\hline
\end{tabular}

Source: Survey 2009.

55.3 per cent in SBA. The data also show that relationships of trust are relatively generalised and play an important role in the structure of daily life in local communities. However, in both municipalities, there is a very clear link between age and the level of mutual trust (Table 1). Younger people show a lower predisposition to trust all their neighbours (2I per cent in SBA and 45.2 per cent in Alcoutim).

The fact that levels of general trust are lower in SBA is due in part to the effects of substantial demographic growth there in recent decades. These are necessarily reflected by forms of social relationships in which the more traditional components become less important. On the other hand, the on-going population loss and permanent marginalisation of Alcoutim are factors that contribute to the continuing existence of more traditional social traits that are specific to rural areas.

\section{Social networks}

This greater differentiation on the part of some social groups can also be found in other dimensions, such as access to certain social networks. For example, having a diversified network of stronger or weaker ties with people who work at important local institutions or organisations is certainly a relevant indicator, which varies on the basis of a number of sociological attributes. To a certain extent, this more focused knowledge, which may be reflected in belonging to more restricted social contact 
Table 2: Knowledge of association leaders and/or municipal council employees by age groups and municipality

\begin{tabular}{llcccc}
\hline & & \multicolumn{3}{c}{ Age } & Total \\
\cline { 3 - 5 } & & Up to 35 & $35-64$ & 65 and over & \\
\hline São Brás de Alportel & None & 32 & 55 & 74 & 161 \\
& & $33.3 \%$ & $32.2 \%$ & $51.7 \%$ & $39.3 \%$ \\
& Average & 30 & 71 & 48 & 149 \\
& & $31.3 \%$ & $41.5 \%$ & $33.6 \%$ & $36.3 \%$ \\
& High & 34 & 45 & 21 & 100 \\
& & $35.4 \%$ & $26.3 \%$ & $14.7 \%$ & $24.4 \%$ \\
& Total & 96 & 171 & 143 & 410 \\
& & $100.0 \%$ & $100.0 \%$ & $100.0 \%$ & $100.0 \%$ \\
& None & 3 & 16 & 21 & 40 \\
& & $7.1 \%$ & $11.0 \%$ & $25.9 \%$ & $14.9 \%$ \\
& Average & 13 & 54 & 39 & 106 \\
& & $31.0 \%$ & $37.2 \%$ & $48.1 \%$ & $39.6 \%$ \\
& High & 26 & 75 & 21 & 122 \\
& & $61.9 \%$ & $51.7 \%$ & $25.9 \%$ & $45.5 \%$ \\
& Total & 42 & 145 & 81 & 268 \\
& & $100.0 \%$ & $100.0 \%$ & $100.0 \%$ & $100.0 \%$ \\
\hline
\end{tabular}

Source: Survey 2009 .

networks, represents additional capital that shows possession of rather privileged factors (Bourdieu i980).

There is a difference when it comes to personal knowledge of people who work at the municipal council and/or who are on the board of a local association and the age variable. Older people are more distanced from this type of privileged knowledge network than people of working age (Table 2). The same applies to educational attainment, as people who have not completed more than primary education have lower levels of privileged knowledge. These data contrast to a certain extent with those on the intensity of mutual knowledge between neighbours, which tends to be more generalised among the elderly and less educated. Nonetheless, in Alcoutim mutual knowledge is stronger, even among the more educated, underlining the more traditional feature of this smaller and much less urbanised municipality.

\section{Civic engagement and membership}

This distinction is also found when it comes to membership of associations. As mentioned above, belonging to and participating in associations is a crucial factor in generating social capital. According to the survey data, 77 per cent of the respondents knew of at least one local association (84.3 per cent in Alcoutim and 72.2 per cent in SBA), though only I9.5 per cent had any knowledge of projects undertaken by associations. Younger people tended to be a little more aware and informed about association activities. Moreover, it was the most qualified respondents that had the highest degree of knowledge of the existence of local associations and/or their projects 
Table 3: Knowledge of associations and/or projects by school attainment

\begin{tabular}{lccccc}
\hline & & \multicolumn{3}{c}{ School attainment } & Total \\
\cline { 3 - 5 } & & Up to primary & $\begin{array}{c}\text { Lower } \\
\text { secondary }\end{array}$ & $\begin{array}{c}\text { Upper secondary } \\
\text { and tertiary }\end{array}$ \\
\hline São Brás de Alportel & None & 81 & 19 & 16 & 116 \\
& & $39.7 \%$ & $18.3 \%$ & $15.7 \%$ & $28.3 \%$ \\
& Average & 115 & 64 & 55 & 234 \\
& & $56.4 \%$ & $61.5 \%$ & $53.9 \%$ & $57.1 \%$ \\
& High & 8 & 21 & 31 & 60 \\
& & $3.9 \%$ & $20.2 \%$ & $30.4 \%$ & $14.6 \%$ \\
& Total & 204 & 104 & 102 & 410 \\
& None & $100.0 \%$ & $100.0 \%$ & $100.0 \%$ & $100.0 \%$ \\
& & 33 & 9 & 1 & 43 \\
& Average & 71 & $11.0 \%$ & $1.6 \%$ & $16.0 \%$ \\
& & $57.3 \%$ & $62.2 \%$ & 31 & 153 \\
& High & 20 & 22 & $50.0 \%$ & $57.1 \%$ \\
& Total & $16.1 \%$ & $26.8 \%$ & 30 & 72 \\
& & 124 & 82 & 62 & $26.9 \%$ \\
& & $100.0 \%$ & $100.0 \%$ & $100.0 \%$ & $100.0 \%$ \\
\hline
\end{tabular}

Source: Survey 2009.

(Table 3): 37.2 per cent knew of at least one local association and one project. Once again, reading the figures for the more educated population combining with the more traditional community (Alcoutim) we see the highest levels of knowledge.

Although around 33 per cent of the respondents said that they were members of an association (43.3 per cent in Alcoutim and 26.3 per cent in SBA), only iI per cent had actually participated in a project. Of those who belonged to associations, 34.8 per cent had already been on the board.

Here there are also differences, mainly between those with the highest school attainment, practically 44 per cent of whom said that they belonged to an association. Different tendencies are now identified: the more educated people are, the less they belong or have belonged to an association and it is SBA that shows higher figures for membership of associations (Table 4). This is also related to the kind of association that prevails nationally and regionally: the associations that have most memberships are the cultural, social or related to sports. For example, the most referred are the firemen associations. Where the sex variable is concerned, there are also some differences, as the men had more knowledge of (82.7 per cent) and belonged more to associations (40.3 per cent) than the women ( 70.6 per cent knew of an association and 25.9 per cent were members).

These data indicate considerable membership of associations, though it is not directly linked to actual active participation in their projects. Nonetheless, if we compare this with other types of belonging and civic engagement, we find that, even so, the associative sector is fairly active. For example, membership of political parties 
Table 4: Membership of an association by school attainment

\begin{tabular}{lccccc}
\hline & & \multicolumn{3}{c}{ School attainment } & Total \\
\cline { 3 - 5 } & & Up to primary & $\begin{array}{c}\text { Lower } \\
\text { secondary }\end{array}$ & $\begin{array}{c}\text { Upper secondary } \\
\text { and tertiary }\end{array}$ \\
\hline São Brás de Alportel & Yes & 160 & 71 & 63 & 294 \\
& & $78.4 \%$ & $68.3 \%$ & $61.8 \%$ & $71.7 \%$ \\
& No & 44 & 33 & 39 & 116 \\
& & $21.6 \%$ & $31.7 \%$ & $38.2 \%$ & $28.3 \%$ \\
Alcoutim & Total & 204 & 104 & 102 & 410 \\
& & $100.0 \%$ & $100.0 \%$ & $100.0 \%$ & $100.0 \%$ \\
& Yes & 84 & 39 & 23 & 146 \\
& & $67.7 \%$ & $47.6 \%$ & $37.1 \%$ & $54.5 \%$ \\
& No & 40 & 43 & 39 & 122 \\
& & $32.3 \%$ & $52.4 \%$ & $62.9 \%$ & $45.5 \%$ \\
& Total & 124 & 82 & 62 & 268 \\
& $100.0 \%$ & $100.0 \%$ & $100.0 \%$ & $100.0 \%$ \\
\hline
\end{tabular}

Source: Survey 2009 .

was substantially lower at around Io per cent. And only 5.3 per cent said that they had held a political office.

The analysis of indicators on certain dimensions of social capital shows a tendency towards the narrowing of answers as the types of ties and civic and social engagement were specified. A comparison of relationships between neighbours shows that there is a wide range of relationships and general degrees of trust. However, as soon as the type of social knowledge networks and forms of civic engagement were mentioned, there was a considerable difference between population groups. It was the younger respondents, especially those with the highest educational attainment, who tended to appropriate the most specific resources and were also therefore the most privileged in terms of social capital. Elderly people tended to be more distanced from these resources. Many factors may contribute to this: they are more distant from the local labour market where this kind of socialisation is crucial, as well as some are also more geographically isolated. However the main reason is probably the national and regional strong correlation between age and education: the older people are the fewer years of schooling they have. So, conflicting tendencies produced this output: if age could provide a greater involvement through longer years of community living that could enhance privileged knowledge, less education and the distance from local labour market reverse this predisposition. Moreover, this tendency is weaker in Alcoutim, where in a smaller and less urbanised community even the less educated have more access to privileged knowledge. Also, it is among the eldest that there are broader relationships and degrees of trust among neighbours.

\section{Multivariate analysis: social capital profiles}

After describing the different variables that characterise some dimensions of social capital, we will now conduct a multiple-correspondence multivariate analysis to 
Table 5: Discrimination measures

\begin{tabular}{lccc}
\hline Variables & \multicolumn{2}{c}{ Dimension } & Mean \\
\cline { 2 - 3 } & 1 & 2 & \\
\hline Length of residence & 0.048 & 0.227 & 0.138 \\
Work or study outside the municipality & 0.211 & 0.114 & 0.162 \\
Knows neighbours & 0.017 & 0.478 & 0.248 \\
Talking to neighbours & 0.028 & 0.440 & 0.234 \\
Trust in neighbours & 0.042 & 0.330 & 0.186 \\
School attainment & 0.698 & 0.058 & 0.378 \\
Social class & 0.229 & 0.060 & 0.145 \\
Age & 0.660 & 0.154 & 0.407 \\
Mobility index & 0.587 & 0.061 & 0.324 \\
Membership in any association & 0.265 & 0.166 & 0.216 \\
Knowledge of association leaders or someone who & 0.328 & 0.337 & 0.332 \\
$\quad$ works in the local government & & & \\
Knowledge of associations or projects & 0.426 & 0.221 & 0.323 \\
Municipality & 0.021 & 0.170 & 0.095 \\
Active total & 3.539 & 2.645 & 3.092 \\
\hline
\end{tabular}

Note: Bold values identify the variables that contribute the most to the definition of each dimension. Source: Survey 2009.

identify the dominant profiles in the social space. One of the advantages of this method is the possibility of a graphic representation of the multiple connections between the categories making up the variables and the projection of the position of each object (individual) on a factorial plot. The configuration of the plot is the result of cross-referencing two factors (or dimensions) formed by the polarisation established by the levels of discrimination ${ }^{4}$ of the different categories (Table 5). Thus, people with similar response patterns tend to be positioned in co-ordinates close to the factorial plot, unlike others whose response patterns have a different statistical and sociological significance. Graphic proximity therefore indicates a certain statistical homogeneity (Carvalho 2008).

The analysis considered a diversified set of variables from three social capital dimensions: trust between neighbours, knowledge networks and membership of associations. Variables on spatial mobility and social characterisation of the respondents were added to these. An addition variable ${ }^{5}$ on municipality of residence was also included. Using the connection and opposition between the categories made by these variables, the aim was to measure different dispositions of more or less salient forms of social capital identified in the social space.

\section{The factorial plot}

Taking the discrimination measures into account, we find that the variables that contribute most to the polarisation of dimension I are those referring to intensity of mobility and to social networks and membership of associations. Dimension 2 is marked by the variables on mutual knowledge and generalised trust between 


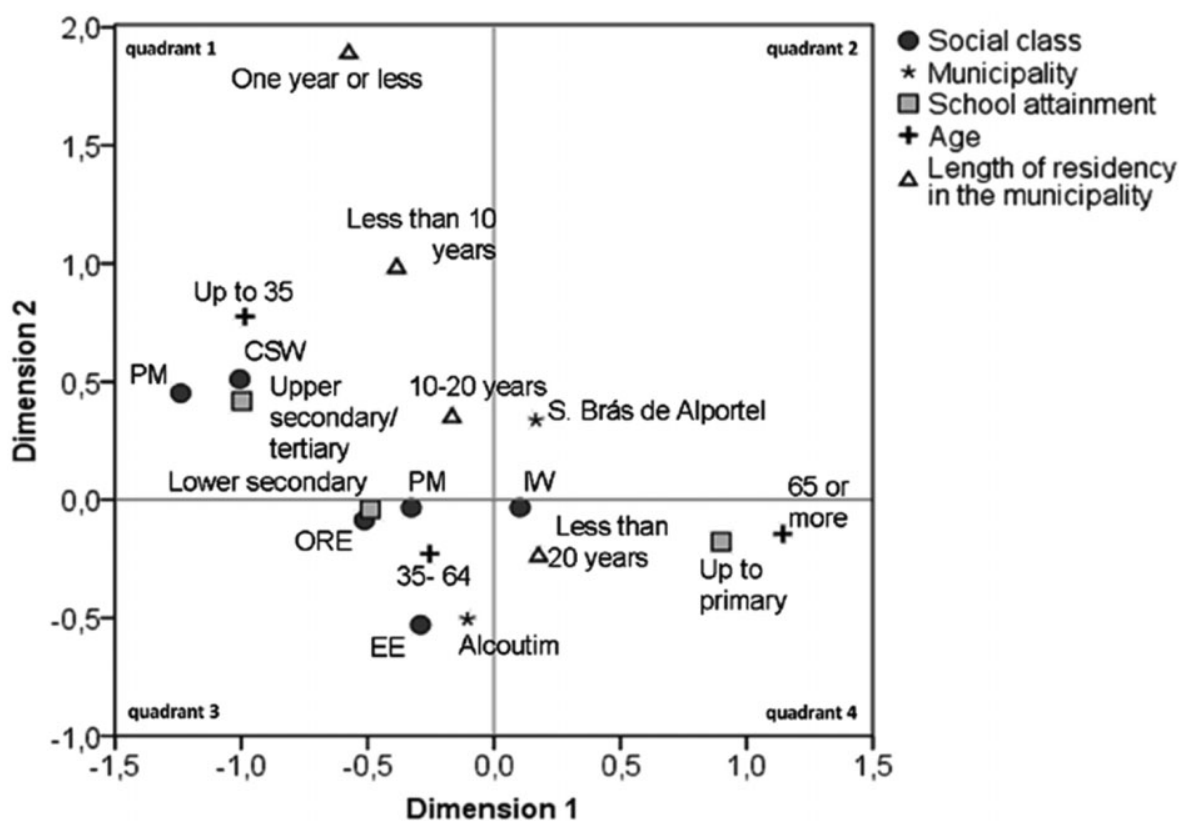

Figure 2: Multiple correspondence analysis - variable principal normalisation for dimensions 1 and 2

neighbours. Knowledge of association leaders and/or council employees contributes to the two dimensions but leans more towards dimension I (Table 5).

The first dimension establishes an opposition in terms of networks of more privileged knowledge (associated with intensity of spatial mobility), while the second opposes those that have generalised relationships of interpersonal trust between neighbours to others that tend to be more selective and restricted in this type of social relationship. According to this composition of the factorial plot, it is possible to say that greater trust and mutual knowledge may not be a condition for access to the most privileged networks.

This piece of information is clearer if the positioning of the characterisation variables is considered (Figure 2). As expected, there is a tendency for older, less educated people and residents living longer in the municipality to be located in the quadrant that cross-references greater trust and generalised mutual knowledge with lower access to the most privileged knowledge network and also lower mobility (quadrant 4). Younger and more educated people and residents of the municipality for less than io years tend to be in opposite positions i.e., lower degrees of generalised trust, more privileged networks and more mobility (quadrant $\mathrm{I}$ ). Where social classes ${ }^{6}$ are concerned, it is interesting to note that clerical support workers and technicians and associate professionals are closer to the positions for this last pole (quadrant $\mathrm{I}$ ) less generalised trust and more privileged networking - while entrepreneurs and executives tend to be at the extreme identifying the highest level of mutual knowledge 


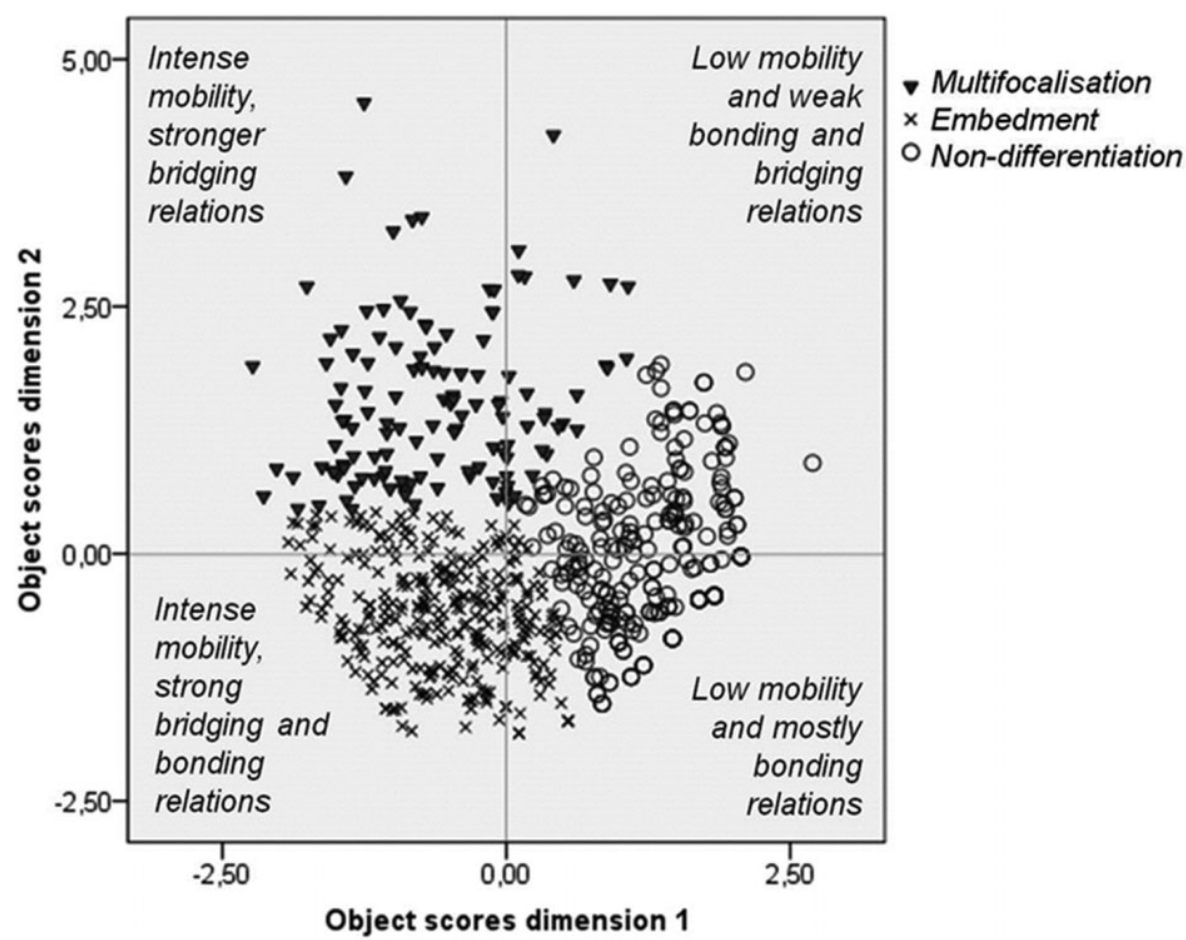

Figure 3: Cluster analysis - object scores for dimension 1 and 2 Source: Survey 2009.

and generalised trust (quadrant 3). This reading should bear in mind that the large majority of this last group is composed of owners/managers of small businesses, like restaurants/snack-bars or groceries while the other group is composed of better qualified workers, thus confirming the previous readings.

This configuration is not surprising, considering the above description of the variables in question. In any case, it was decided that it would be interesting to define the dominant profiles emerging from the multivariate analysis.

Cluster analysis: three profiles

A cluster analysis was therefore conducted from the identified dimensions. Each cluster contains individuals who share a set of sociological characteristics, thereby maximising the statistical proximity between them. As a result, it is possible to obtain information about the cluster size in relation to the number of individuals that compose it. Projection on the plot makes it possible to interpret the profile of each set.

Figure 3 shows a graphic representation of the three clusters in the factorial plot. Using the previously defined co-ordinates as a reference, it is possible to stipulate a 
typology of profiles for the different forms of social capital. As seen above, these are populations that, due to a number of identified characteristics, tend to keep up mutual knowledge and generalised relations with neighbours. However, in spite of this general scenario, a more detailed analysis establishes different positions based on the diverse dimensions of social capital.

We found that part of the population, especially older people, tended to trust and have relationships with all or almost all their neighbours. This profile corresponds to a great extent to the cluster called non-differentiation (35.I per cent of the respondents). In other words, although they have this general degree of knowledge and trust, they do not access the most differentiated and, to a certain extent, most privileged networks.

The next cluster (46.5 per cent) is the one with the most respondents and shows mid-level attributes not only in terms of social characteristics (age, school attainment and time of residence in the municipality), but also of forms of social capital. We have called it embedment, precisely because the people in it combine trust and generalised mutual knowledge with a capacity for having more distinct, privileged social networks. They also show regular patterns of spatial mobility.

The multifocalisation profile gathers I8.4 per cent of the respondents. This is a less homogeneous cluster than the previous one, as shown by its greater dispersal in the upper quadrants of the plot. It tends to include younger, more educated people who have no generalised trust in their neighbours and therefore have a very limited degree of mutual knowledge. However, a significant part of this group develops more focalised, relatively privileged knowledge networks. This focalisation may be inside or outside the municipality, in that this is a population with higher levels of mobility than the previous one, as they visit family or friends outside the municipality more frequently. This cluster can therefore be considered to have social capital focused on different social circulars, some of them of a more distinctive nature.

Considering these three profiles, it is possible to fit in the forms of social capital called bridging and bonding. As mentioned in the introduction, they should not be interpreted homogeneously, as their significance is the result of the interconnection of different social dynamics. If the non-differentiation profile is mostly based on more forms of bonding, it therefore seems clear that the other forms of social capital can be found in the two other clusters. There are, however, different positioning between them.

In the case of the embedment profile, there seems to be a balance between extended development of internal relationships of trust and an increase in more privileged knowledge networks. In other words, there is bonding and bridging here that, although external and mobility links, tend to be channelled towards strengthening internal networks reflected in mutual trust and knowledge.

Multifocalisation profile (in spite of lower internal homogeneity) is closer to bridging, in which priority goes to differentiated relationships often directed outside the area of residence.

If we cross-reference these three profiles on the basis of municipality of residence, there are some differences in distribution that are worth noting (Table 6). The embedment profile is dominant in Alcoutim and includes more than 64 per cent of the respondents in the municipality. In SBA, there is a degree of polarisation between the 
Table 6: Social capital profile by municipality of residence

\begin{tabular}{lcccc}
\hline & & \multicolumn{2}{c}{ Municipality } & Total \\
\cline { 3 - 4 } & & São Brás de Alportel & Alcoutim & \\
\hline Multifocalisation & $\mathrm{N}$ & 108 & 17 & 125 \\
& $\%$ & $26.3 \%$ & $6.3 \%$ & $18.4 \%$ \\
Embedment & $\mathrm{N}$ & 142 & 173 & 315 \\
& $\%$ & $34.6 \%$ & $64.6 \%$ & $46.5 \%$ \\
Non-differentiation & $\mathrm{N}$ & 160 & 78 & 238 \\
& $\%$ & $39.0 \%$ & $29.1 \%$ & $35.1 \%$ \\
Total & $\mathrm{N}$ & 410 & 268 & 678 \\
& $\%$ & $100.0 \%$ & $100.0 \%$ & $100.0 \%$ \\
\hline
\end{tabular}

Source: Survey 2009.

non-differentiation profile (39 per cent of the residents) and the multifocalisation profile (26.3 per cent).

These differences are linked to the phenomena mentioned above: more traditional relationships focusing on mutual knowledge and trust between neighbours (which tend to coexist with others), and more directed forms of knowledge networks, still prevail in Alcoutim. As SBA was experiencing an on-going process of population growth and some urbanisation, there is greater contrast between the multifocalisation profile, which gives priority to differentiated relationships (many of them bridging), and the non-differentiation profile involving the older and less mobile population.

The multifocalisation profile in SBA certainly demonstrates the recent transformations that this municipality has undergone. The composition of this cluster is also due to an increase in new residents who, although they moved to the municipality, not only maintain but also develop social networks with groups and individuals outside it, as was shown in the much higher percentage of people working outside the municipality (see above).

\section{Conclusion}

In the last decades, the changes in these two municipalities are reflected in the greater differentiation and complexity of forms of social capital. There is, in fact, a relevant distinction considering certain social groups and categories. Among them, there is a notable difference on the basis of age and school attainment. Also, these local contexts report consequences of continuing marginalisation of rural spaces (Alcoutim) and, on the contrary, growing villages (SBA) due to better integration in regional/urban space.

Most of the older population fit into a social profile very close to the bonding forms of relationships characteristic of more traditional rural communities, where generalised mutual trust and knowledge between neighbours predominated. They continue to be of considerable importance, although they are no longer prevalent.

Meanwhile, the younger and intermediate age groups and people with the highest school attainment tend to develop more focused relationships that point to more privileged knowledge networks. Many of these links are developed outside the 
municipalities, which indicate a propensity for increasing bridging forms of social capital. This is partly associated with spatial mobility practices, which have become considerably more frequent in these groups.

The aim of the analytical parallel established between the concepts of community and social capital was to test the impact that structural changes have had on many rural localities. These changes obviously vary considerably on the basis of geographical and social contexts, and one cannot establish a uniform view of these processes. In any case, the central point of our argument is that many rural communities have been embracing other forms of relationship between their residents and that they are necessarily expressed in more complex, diversified types of social capital.

Considering the comparison between the two municipalities in question, there is greater polarisation between the multifocalisation and non-differentiation profiles in SBA. This is related to some extent to the recent socio-demographic transformations that have occurred there and has resulted in a more pronounced change in traditional forms of relationship. In Alcoutim, however, this type of relationship is still dominant and there is therefore a much smaller margin for the development of forms of social capital that tend to focus more on privileged knowledge networks (both within and outside the community). In fact, the relatively isolated geographical location of Alcoutim, a municipality with a population four times smaller than that of SBA, is an inescapable factor that favours the preservation of more traditional forms of relationship.

In this sense, we follow Urry's thoughts on how the lack of mobility weakens social capital. We would however make an addendum: in the case of Alcoutim it has weakened privileged networking and has 'helped' to maintain the more traditional community building. Moreover, marginalisation here also means the maintenance of the elderly, also less qualified, in the municipality while the younger had to leave to find work elsewhere. The demographic dimension and spatial marginality - or, on the other hand, integration in regional urban network - are factors to be considered.

The more integrated and less marginalised space (S. Brás de Alportel) is inhabited by younger and more qualified people. So, if it was the local proximity of the regional capital that may have promoted their moving into the municipality and renewing it, these are also people that were already more mobile due to their socio-demographic features and resources as well as more focused in their social contacts. The relation between mobility and social capital is complex because we can be addressing different types of mobility and different profiles of social capital, as shown.

\section{Notes}

* Corresponding author.

I 'Associations' can be defined as 'service-providing organisations that supplement or complement public services in such areas as health, education, and social welfare, and organisations that offer mechanisms through which individuals can join together to address community needs, participate in political life, and pursue individual and group interests' (Franco et al. 2005, p. 8). In our survey, to give some examples, people declared to be members of groups such as the association linked to local voluntary firemen, which helps to financially support their activity; hunting, fishing and motorcycle clubs; trade unions or professional associations; local associations that promote cultural activities (concerts, local 
products markets, folklore festival ...); environmental national or regional associations, within others.

2 The survey was applied in the context of CIES-IUL project, funded by FCT, entitled 'Voluntary associations and local development: public policies, social capital and citizenship' (Ref: PTDC/SDE/69882/2006).

3 All these data are from: INE (200I, 2009, 20II).

4 'Discrimination measures quantify the variance of each variable, and so the closer its value is to the upper limit (i.e., I), the more the variables in question discriminate the objects being analysed' (Carvalho 2008, p. 75).

5 This is merely illustrative, as its distribution does not contribute to the composition of the factors.

6 The ACM topology was used as a reference (Almeida et al. 2006): Clerical support workers (CSW); Professionals and managers (PM); Other routine employees (ORE); Industrial workers (IW); Entrepreneurs and executives (EE); Self-employed (SE).

7 This index measures the overall intensity of mobilities for non-work time and is the result of aggregating six variables: supermarket shopping, going to shops and shopping centres, going to the cinema, theatre and concerts, visiting friends or family, going to restaurants and cafés and going to bars and clubs.

\section{References}

Almeida, J.F., F.L. Machado and A.F. Costa (2006) Social classes and values in Europe. Portuguese Journal of Social Science 5 (2) pp. 95-II7

Amit, V. (2002) Reconceptualizing community. Pp. I-20 in V. Amit ed., Realizing community: concepts, social relationships and sentiments (London, New Yourk: Routledge)

Anderson, C. and M. Bell (2003) The devil of social capital: a dilemma of American rural Sociology. Pp. 232-244 in P. Cloke ed., Country visions (Harlow: Pearson Prentice Hall)

Bell, C. and H. Newby (I97I) Community studies: an introduction to the sociology of local community (London: George Allen \& Unwin)

Bourdieu, P. (I980) Le capital social: notes provisoires. Actes De La Recherche En Sciences Sociales 3I pp. 2-3

Calhoun, C.J. (I980) Community: toward a variable conceptualization for comparative research. Social History 5 (I) pp. I05-I29

Calhoun, C.J. (I99I) Indirect relationships and imagined communities: large scale integration and transformation of everyday life. Pp. 95-I20 in P. Bourdieu and J. Coleman eds, Social theory for a changing society (Boulder and New York: Westview Press/Russel Sage Fundation)

Camarero, L. (I993) Del Éxodo Rural y del Éxodo Urbano. Ocaso y Renacimiento de los Asentamientos Rurales en España (Madrid: Ministerio de Agricultura Pesca y Alimentación)

Campbell, A., J. Hughes, M. Hewstone et al. (2010) Social capital as a mechanism for building a sustainable society in northern Ireland. Community Development Journal 45 (I) pp. $22-38$

Carmo, R.M. (2009) A construção sociológica do espaço rural: da oposição à apropriação. Sociologias 2I pp. 252-280

Carmo, R.M. (20I0) Albernoa revisited: tracking social capital in a Portuguese village. Sociologia Ruralis 50 (I) pp. I5-30

Carvalho, H. (2008) Análise Multivariada de Dados Qualitativos: Utilização da Análise de Correspondências Múltiplas com o SPSS (Lisbon: Edições Sílabo)

Coleman, J. (I990) Foundations of social theory (Cambridge: Belknap Press of Harvard University Press)

Dale, A. and L. Newman (20I0) Social capital: a necessary and sufficient condition for sustainable community development? Community Development Journal 45 (I) pp. 5-2I 
Falk, I. and S. Kilpatrick (2000) 'What is social capital?': a study of interaction in a rural community. Sociologia Ruralis 40 (I) pp. 87-IIO

Ficher, C.S. (1977) Network and places (New York: The Free Press)

Foley, M.W., B. Edwards and M. Diani (200I) Social capital reconsidered. Pp. 266-280 in B. Edwards and M.W. Foley eds, Beyond Tocqueville: civil society and the social capital debate in comparative perspective (New England: Tufts University)

Franco, R.C., S.W. Sokolowski, E.M.H. Hairel et al. (2005) The Portuguese nonprofit sector in comparative perspective (Lisbon: Universidade Católica Portuguesa e Jonhs Hopkins University)

Frykman, J., M. Hammarlin, K. Hansen et al. (2009) Sense of community: trust, hope and worries in the welfare state. Ethnologia Europaea - Journal of European Ethnology 39 (I) pp. $7-46$

Granovetter, M.S. (I973) The strength of weak ties. American Journal of Sociology 78 (6) pp. $136 \mathrm{I}-\mathrm{I} 38 \mathrm{O}$

Halpern, D. (2005) Social capital (Cambridge: Polity Press)

Harriss, J. (200I) Depoliticizing development: the world bank and social capital (London: Anthem Press)

Hedberg, C. and R.M. Carmo (2012) Translocal ruralism: mobility and connectivity in European rural spaces (Dordrecht, London: Springer)

INE (200I) Recenseamento Geral da População (Lisbon: Instituto Nacional de Estatística)

INE (2009) Anuário Estatístico da Região do Algarve (Lisbon: Instituto Nacional de Estatística)

INE (20II) Recenseamento Geral da População (Lisbon: Instituto Nacional de Estatística)

Johnston, R., C. Propper, R. Sarker et al. (2005) Neighbourhood social capital and neighbourhood effects. Environment and Planning A 37 pp. I443-I459

Jollivet, M. (1997) Les metamorphoses d'un rural incertain. Pp. 35I-37I in M. Jollivet ed., Vers un Rural Postindustrial (Paris: L'Harmattan)

Kayser, B. (I990) la renaissance rural (Paris: Armand Colin)

Lee, J., A. Árnason, A. Nightingale et al. (2005) Networking: social capital and identities in European rural development. Sociologia Ruralis 45 (4) pp. 27I-283

Liepins, R. (2000) New energies for an old idea: reworking approaches to 'community' in contemporary rural studies. Journal of Rural Studies I6 (I) pp. 23-35

Lin, N. (200I) Social capital: a theory of social structure and action (Cambridge: Cambridge University Press)

McAreavey, R. (2009) Rural development theory and practice (London: Routledge)

Magnani, N. and L. Struffi (2009) Translation sociology and social capital in rural development initiatives: a case study from the Italian Alps. Journal of Rural Studies 25 pp. 23I-238

Mendras, H. (1976) Sociétés paysannes (Paris: Armand Colin)

Milbourne, P. (2007) Re-populating rural studies: migrations, movements and mobilities. Journal of Rural Studies 23 pp. 38I-386

Murdoch, J. (2000) Networks - a new paradigm of rural development? Journal of Rural Studies I6 pp. 407-4I9

Nardone, G., R. Sisto and A. Lopolito (20I0) Social capital in the LEADER initiative: a methodological approach. Journal of Rural Studies 26 pp. 63-72

Nguyen, D. (20I0) Evidence of the impacts of urban sprawl on social capital. Environment and Planning $B 37$ pp. 610-627

Nisbet, R.A. (I966) The sociological tradition (London: Heinemann Educational Books)

Perrier-Cornet, P. and B. Hervieu (2002) Les transformations des campagnes françaises: une vue d'ensemble. Pp. 9-34 in P. Perrier-Cornet ed., Repenser les Campagnes (Datar, Gémenos: Éditions de l'Aube)

Pinto, J.M. (I985) Estruturas Sociais e Práticas Simbólico-ideológicas nos Campos: Elementos de Teoria e de Pesquisa Empírica (Porto: Edições Afrontamento) 
Portes, A. (I998) Social capital: its origins and applications in modern sociology. Annual Review Sociology 24 pp. I-24

Putnam, R. (I993) Making democracy work: civic traditions in modern Italy (Princeton, NJ: Princeton University Press)

Putnam, R. (2000) Bowling alone: the collapse and revival of American community (New York: Simon \& Schuster)

Redfield, R. (I989 [1960]) The little community and peasant society and culture (Chicago: The University Chicago Press)

Rémy, J. and L. Voyé (I994) A Cidade: Rumo a uma Nova Definição? (Porto: Edições Afrontamento)

Schucksmith, M. (2000) Endogenous development, social capital, and social inclusion: perspectives from LEADER in the UK. Sociologia Ruralis 40 (2) pp. II7-I33

Shortall, S. (2008) Are rural development programmes socially inclusive? Social inclusion, civic engagement, participation, and social capital: exploring the differences. Journal of Rural Studies 24 pp. $450-457$

Shuller, T., S. Baron and J. Field (2000) Social capital: a review and critique. Pp. I-38 in S. Baron, J. Field and T. Schuller eds, Social capital: critical perspectives (Oxford: Oxford University Press)

Sobral, J.M. (I999) Trajectos: o presente e o passado na vida de uma freguesia da Beira (Lisbon: Imprensa de Ciências Sociais)

Svendsen, G.L.H. and G.T. Svendsen (2004) The creation and destruction of social capital: entrepreneurship, co-operative movements and institutions (Cheltenham: Edward Elgar)

Urry, J. (2002) Mobility and proximity. Sociology 36 (2) pp. 255-274

Van Deth, J.W. (2003) Measuring social capital: orthodoxies and continuing controversies. International Journal of Social Research Methodology 6 (I) pp. 79-92

Wellman, B. (I979) The comumunity question: the intimate networks of East Yorkers. American Journal of Sociology 84 (5) pp. I2OI-I23I

Wilshusen, P.R. (2009) Shades of social capital: elite persistence and everyday politics of community forestry in southeastern Mexico. Environment and Planning A 4I pp. 389-406

Woods, M. (2007) Engaging the global countryside: globalization, hybridity and the reconstitution of rural place. Progress in Human Geography 3I pp. 485-507

Woolcock, M. (I998) Social capital and economic development: toward a theoretical synthesis and policy framework. Theory and Society 27 (2) pp. I5I-208

Worsley, P. (I970) Modern sociology: introductory readings (Harmondsworth: Penguin)

Renato Miguel Carmo*

CIES

Instituto Universitário de Lisboa

Edifício ISCTE, Av. das Forças Armadas

1649-026 Lisboa

Portugal

e-mail: renato.miguel.carmo@gmail.com; renato.carmo@iscte.pt

Sofia Santos

CIES

Instituto Universitário de Lisboa

Edifício ISCTE, Av. das Forças Armadas

1649-026 Lisboa

Portugal 